\title{
Biološka raznolikost u urbanom planiranju
}

\author{
DAMIR VILIČIĆ*
}

Sveučilište u Zagrebu, Prirodoslovno-matematički fakultet, Biološki odsjek, Rooseveltov trg 6, 10000 Zagreb, Hrvatska

* Autor za dopisivanje / corresponding author: damir.vilicic@biol.pmf.hr

Tip članka / article type: stručno priopćenje / professional communication

Povijest članka / article history: primljeno / received: 19.11.2019., prihvaćeno / accepted: 19.4.2020.

URL: https://doi.org/10.46232/glashbod.8.1.4

Viličić, D. (2020): Biološka raznolikost u urbanom planiranju. Glas. Hrvat. bot. druš. 8(1): 19-28.

\section{Sažetak}

U velikim gradovima raste potreba za suvremenim urbanim planiranjem. Urbano planiranje uključuje krajobrazno oblikovanje, krajobraznu ekologiju i inovativna rješenja. „Zelena tehnologija“ i veća biološka raznolikost čini „zeleni servis“ grada koji omogućava zdraviji i jeftiniji život građana. Ekološko uređivanje javnih površina i privatnih vrtova treba biti u skladu s globalnim projektom o urbanoj biološkoj raznolikosti kojem je primjerice grad Zagreb pristupio još 2007. godine. Osnovni cilj tog projekta sastoji se u osmišljavanju koridora kojim se povezuju javne površine i privatni vrtovi u središtu grada s prirodnim okolišem u njegovoj okolici.

Ključne riječi: Biološka raznolikost, ekološka zaštita, ekološko održavanje, javni parkovi, privatni vrtovi, urbani okoliš, urbano planiranje, zelena tehnologija

Viličić, D. (2020): Biological diversity in urban planning. Glas. Hrvat. bot. druš. 8(1): 19-28.

\section{Abstract}

Large cities provide increasing need for modern urban planning. Urban planning involves landscape design, landscape ecology and innovative solutions. "Green technology" and greater biological diversity make "green service" allowing cheaper and healthier citizen's life. Ecological management of public areas and private gardens should be in line with the global project on urban biodiversity which, for example, the city of Zagreb joined in 2007. The main goal of this project consists in creating corridors that connects public spaces and private gardens in the city center with the natural environment around the city.

Key words: Biological diversity, ecological maintenance, ecological protection, green technology, private gardens, public parks, urban environment, urban planning

\section{Principi ekološke zaštite u narušenom okolišu}

U 20. stoljeću ekologija dobiva važnu ulogu jer tada čovjek ubrzano uništava prirodu, stvarajući nepregledna područja s intenzivnom poljoprivredom i gradeći velike gradove. Ekologija nastoji riješiti opstanak čovjeka u narušenom okolišu, a istraživači kvantificiraju ekološke procese, 


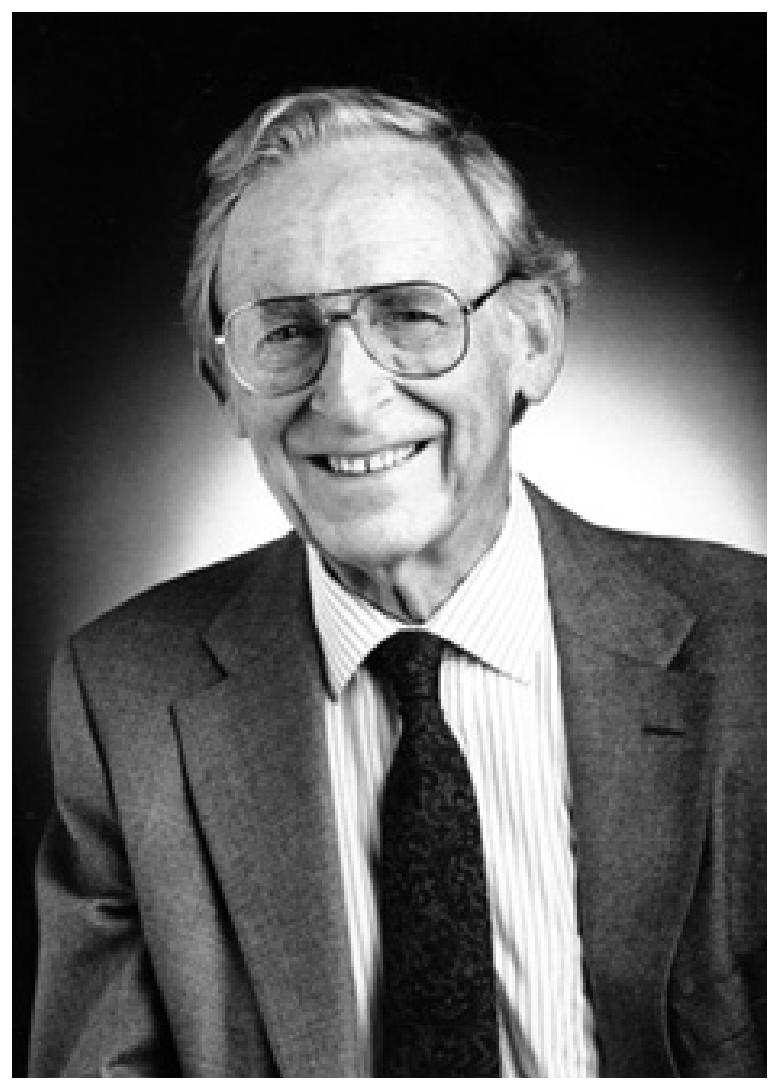

Slika 1. Eugen Odum (1913-2002) - osnivač suvremene ekologije (sliku je objavio Barrett 2003).

npr. Eugen Odum, Alfred J. Lotka, Evelyn Hutchinson i drugi. Eugen Odum (1913-2002) (Sl. 1) osnivač je suvremene ekologije. Najviše se bavio ekološkim sukcesijama koje je povezivao s procesima kao što su brzina produkcije, kretanje biomase, prehrambeni odnosi i naseljavanje organizama u prostoru. Razumijevanjem tih procesa možemo ispraviti poremećaje u prirodi i u narušenom okruženju čovjeka (Odum 1969, Tab. 1). Odum prati procese tijekom mladih i razvijenih stadija sukcesije (S1. 2). Integrirao je ekologiju s drugim znanostima u ,znanost o ekološkom sustavu”. Na osnovama Odumovih teoretskih postavki, recentni autori razvijaju urbanu ekologiju (Adler i Tanner 2013).

Gradovi se razvijaju na površinama koje su primarno bile pokrivene klimatski i edafski uvjetovanom vegetacijom, faunom i mikroorganizmima. U izgrađenom gradu zaostaje mali broj vrsta organizama koje ulaze u sastav različitih vidljivijih ili manje vidljivih komponenata urbanog okoliša (Forman 2014). Odum gradove uspoređuje s nepreglednim poljima pšenice. Takve zajednice u kojima su maksimalno reducirani odnosi između malog broja vrsta neotporne su i podložne bolestima. Poljoprivredne monokulture čovjek tretira otrovima da ne bi propale od biljnih bolesti; tlo postaje sve siromašnije jer prvobitna uništena šumska zajednica više ne stvara novo tlo. Odum je objasnio da je zdraviji život za ljude u gradovima moguće ostvariti povećanjem biološke raznolikosti - organiziranjem mozaičnog rasporeda stambenih naselja, zelenih površina i prirodnih životnih zajednica. Raznolikost organizama i njihovih zajednica stvara složenije prehrambene mreže koje stabiliziraju ekološki sustav, što je kasnije potvrđeno matematičkim modelima (Johnson i sur. 2014). Dokazano je da zelene površine u gradovima pružaju „zdravstveni servis“; reguliraju prijenos bolesti (McMichael i sur. 1999), smanjuju fiziološke poremećaje kao što su diabetes ili srčane bolesti i smanjuju mortalitet ljudi (Hartig 2008).

U gradovima se nastoji razviti održivi i multifunkcionalni koncept planiranja i upravljanja urbanog ekološkog sustava i krajobraza (S1. 3). Koristi se „zelena urbana infrastruktura“ kojom se postiže održivo društveno i ekološko zdravlje u gradovima

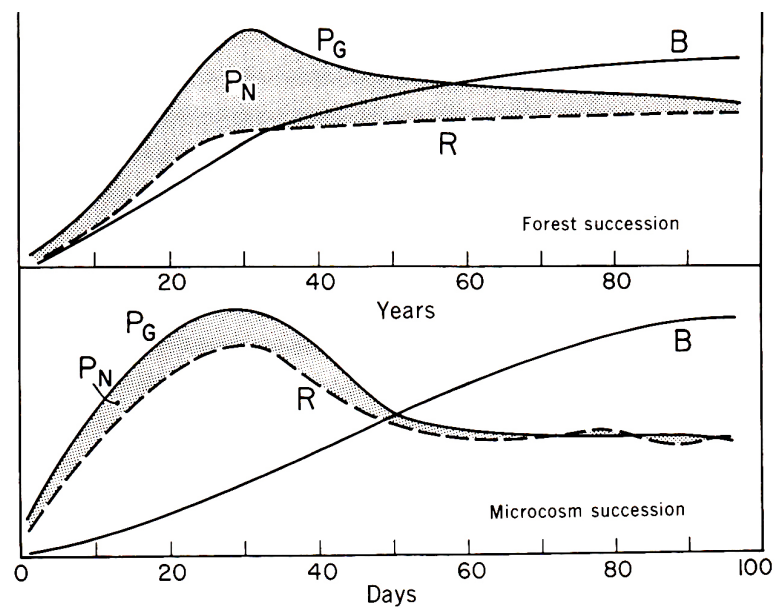

Slika 2. Sukcesija ekološkog sustava - usporedba šume i mikrokozmosa. PG - gros produkcija, PN neto produkcija, B - biomasa, $\mathrm{R}$ - respiracija (prema Odumu 1969). 
Tablica 1. Svojstva ekološkog sustava tijekom sukcesije prema Odumu (1969).

\begin{tabular}{|c|c|c|c|}
\hline & Svostva ekološkog sustava & Rani stadij & Razvijeni stadij \\
\hline 1 & Brzina produkcije/biomasa & $>1$ & $<1$ \\
\hline 2 & Prehrambeni odnosi & Linearni & Hranidbena mreža \\
\hline 3 & Ukupna organska tvar & Malo & Mnogo \\
\hline 4 & Anorgansk hranjiva tvar & Ekstracelularno & Intracelularno \\
\hline 5 & Raznolikost vrsta & Mala & Velika \\
\hline 6 & Biokemijska raznolikost & Mala & Velika \\
\hline 7 & Prostorna heterogenost & Mala & Velika \\
\hline 8 & Životni ciklusi & Kratki, jednostavni & Dugi, složeni \\
\hline 9 & Uloga detritusa & Mala & Velika \\
\hline 10 & Brzina rastenja & Velika ("r-selekcija") & Mala ("k-selekcija") \\
\hline 11 & Simbiontski odnosi & Zanemarivi & Razvijeni \\
\hline 12 & Utjecaj metabolita na jedinke u zajednici & Mali & Veliki \\
\hline 13 & Entropija & Velika & Mala \\
\hline 14 & $\begin{array}{l}\text { Stabilnost (otpornost prema } \\
\text { vanjskim poremećajima) }\end{array}$ & Slaba & Dobra \\
\hline
\end{tabular}


MULTIFUNKCIONALNOST
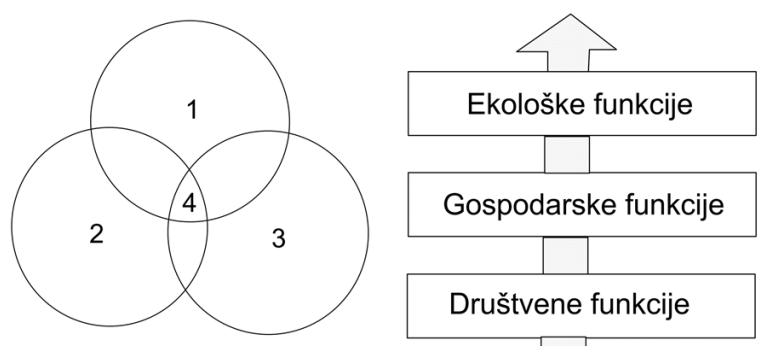

Slika3. Koncept održivog i multifunkcionalnog. Održivo stanje (4) nastaje ako su zadovoljeni zahtjevi okoliša (1) te gospodarski (2) i socijalni (3) čimbenici (prema Giddingsu i sur. 2002). Multifunkcionalnost označava postizanje boljih uvjeta za život uz prihvatljive društvene i proizvodne funkcije te funkcije okoliša (Prema Taylor Lovell i Taylor 2013).

(Giddings i sur. 2002, Taylor Lovell i Taylor 2013, Taylor i Hochuli 2015). Zelena infrastruktura uključuje u urbani okoliš drveće; travnjake, parkove; gradske šume; urbanu poljoprivredu; vlažna staništa; jezera, potoke, a takva staništa naseljava i pripadna fauna (Bolund i Hunhammar 1999). Urbane zelene površine omogućavaju biološku raznolikost, održavanje pogodnih mikroklimatskih uvjeta, infiltraciju vode u tlo, vezanje ugljik dioksida, vizualnu i estetsku kvalitetu, rekreaciju i društveni kapital. Urbana poljoprivreda sve je značajnija djelatnost koja doprinosi ekonomskoj održivosti i zelenoj infrastrukturi gradova (Wortman i Taylor Lovell 2013). Vegetacija u gradovima smanjuje buku. Gubitak zelenih površina i biološke raznolikosti djeluje negativno na stanovnike u gradovima (Pedersen Zari 2018), jer se narušavaju mikroklimatski uvjeti za život, narušava se urbana cjelina (u slučaju različitih katastrofa), rastu troškovi, stanovništvo se seli, suši se tlo, opada kvaliteta zraka i razina podzemnih voda, ugroženo je zdravlje ljudi zbog pojave štetočina i bolesti.

\section{Zelena infrastruktura i prostorno planiranje}

Zagreb je najveći grad u Hrvatskoj, ali je još uvijek bogat zelenilom, pa se u njemu još ne pojavljuju ekološke krize kao u mnogim megalopolisima svijeta. Zelenu infrastrukturu u gradu treba razvijati prije nego se jave krizne situacije zbog pretjerane betonizacije. Po preporuci UN i EU, $\mathrm{u}$ turističkim gradovima treba razvijati koncept zelenog turizma, čime se jačaju konkurentnost $i$ poduzetničke prilike (Carić 2016). U Zagrebu je još 2007. godine održana prva međunarodna radionica o biološkoj raznolikosti u gradovima ("Local Action for Biodiversity Workshop”), u okviru globalnog projekta o urbanoj biološkoj raznolikosti (engl. "Global urban biodiversity project"). Zamišljeno je da projekt ubuduće bude forum za rješavanje problema betonizacije velikih gradova. Zdraviji život u takvim sredinama moguće je provesti u skladu s osnovnim načelima ekologije i principima kojima ekolozi objašnjavaju stabilnost ekološkog sustava. Posebno veliku ulogu u povećavanju i održavanju biološke raznolikosti u gradovima imaju stanovnici koji uređuju vlastite vrtove na ekološki prihvatljiv način (Gaston i sur. 2005, van Heezik i sur. 2014). Time se postižu ugodniji mikroklimatski uvjeti i sve što donosi stabilniji okoliš. U vrtovima treba saditi raznoliko bjelogorično grmlje i živice, a listinac koji pada na tlo ili u kompostištima mikrobnom aktivnošću obnavlja tlo. Male prirodne livadne zajednice, šumsko drveće i grmlje u mozaičnom rasporedu omogućavaju razvoj odgovarajuće faune (leptiri, mali sisavci, ježevi, ptice). Pokazalo se da građani u razvijenim zemljama svijeta s razumijevanjem prihvaćaju život uz takav koncept, uz veću biološku raznolikost u svojim vrtovima. Male životne zajednice u privatnim vrtovima i u ekološki upravljanim javnim parkovima mogu na taj način ostati povezane s periferijom grada u kojoj je ostao nepromijenjen okoliš.

Suvremeno prostorno planiranje zahtijeva od urbanista, arhitekata i krajobraznih arhitekata da se ne bave isključivo prostornim i društvenim aspektom uređenja izgrađenog prostora, već da uzimaju u obzir i krajobraznu ekologiju. Zelenu infrastrukturu uvode poznavanjem ekologije, pa je za to potrebna prvenstveno suradnja s biolozima. Interdisciplinarna suradnja između arhitekata, krajobraznih arhitekata, ekologa, urbanih 
sociologa, šumara, agronoma i drugih najbolje integrira estetiku i ekologiju. Krajobrazni arhitekti i urbanisti danas analiziraju i kvantitativno vrednuju funkcionalne indikatore elemenata za postizanje multifunkcionalnog pristupa uređenju krajobraza. Analiziraju elemente pojedinih okolišnih, gospodarskih i društvenih funkcija na terenu. Zbrajaju i procjenjuju indikatore pojedinih strukturnih i ekoloških kategorija prostora i predlažu najbolje odnose u prostoru (Taylor Lovell i Taylor 2013). Ozelenjavanje se najuspješnije provodi s domaćim dekorativnim drvećem i grmljem koje je najbolje prilagođeno na klimatske i pedološke osobine područja (Šišić 2003).

Za provođenje ideja o zelenoj infrastrukturi potrebna je edukacija iz ekologije te javna rasprava s građanima. Trenutno aktualne koncepte zelene infrastrukture u Zagrebu i ostalim gradovima Hrvatske, gdje već postoje izrađene studije i strategije razvoja zelene infrastrukture, treba stalno poboljšavati interdisciplinarnom suradnjom. U Zagrebu se neki javni parkovi projektiraju i oblikuju uzimajući u obzir uglavnom estetske (Pereković i sur. 2007) i rekreacijske vrijednosti urbanog krajobraza (Pereković i Kamenečki 2017). Narednom izgradnjom grada Zagreba potrebno je štititi zatečene prirodne vrijednosti, koje bi mogle biti osnovica buduće zelene infrastrukture (Price i sur. 2019).

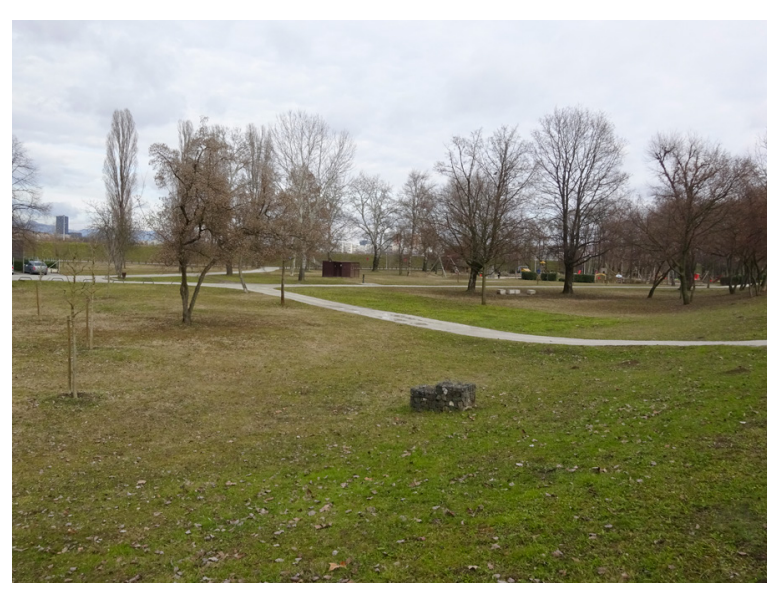

Slika 4. Rekreacijska zona Bundek s nedostatkom grmlja i malom biološkom raznolikošću.

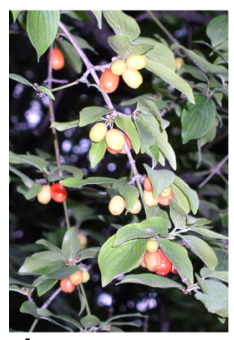

A

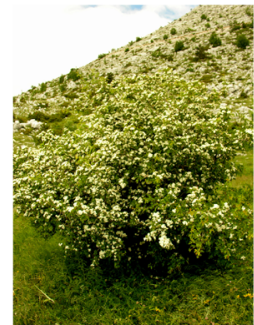

B

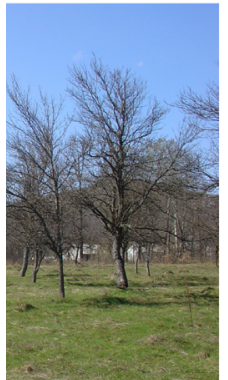

D

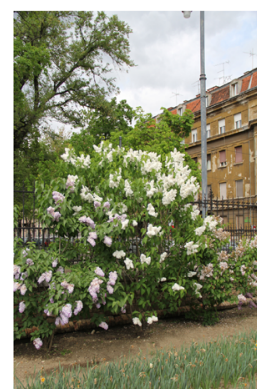

E

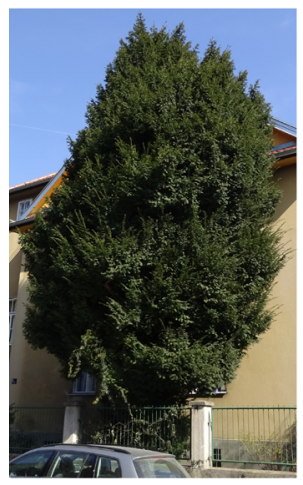

G

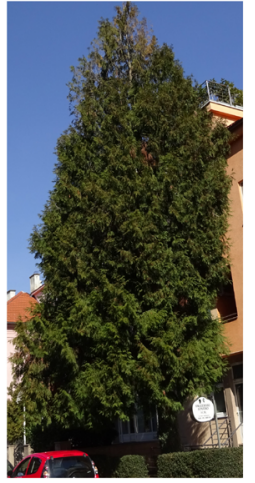

$\mathrm{H}$

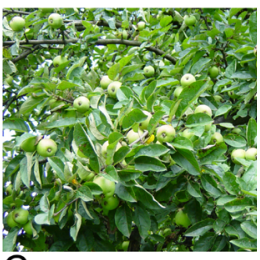

C

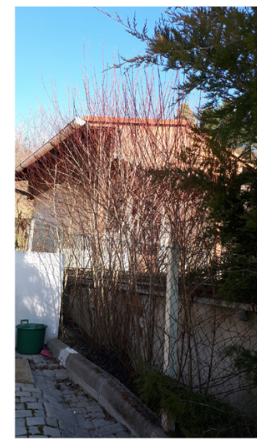

$\mathrm{F}$

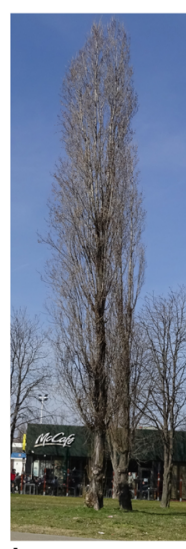

I

Slika 5. Neke pogodne vrste/rodovi za sadnju u hortikulturi i u privatnim vrtovima (v. Tab. 2) u kontinerntalnom dijelu Hrvatske; drijen (A), glog (B), jabuka (C), šljiva (D), jorgovan (E), svib (F), tisa (G), lawsonov pačempres (H), jablan (I). Fotografije: A - Vanja Stamenković; B, E - Darko Mihelj; F Zrinka Ljubešić.

Uređenje i održavanje prostora u Zagrebu dobro je provoditi po preporukama globalnog projekta kojem je Zagreb pristupio 2007. godine i koji se dalje razvija (Urban diversity forum HUB). Postoje i drugi slični projekti u svijetu, npr. pokret pod nazivom „Grad vrtova“ (engl. „Garden city movement”), koji podržava urbano planiranje kojim se naselja veličine od tridesetak tisuća stanovnika sa stambenim površinama, industrijom i gradskom poljoprivredom okružuju većim zelenim pojasom. 
Tablica 2. Ekološka i estetska svojstva nekih vrsta drveća i grmova koje se sadi u javnim parkovima i privatnim vrtovima. Nisko grmlje nije uzeto u obzir. Svojstva su bodovana s 1, 3 i 5, a konačni zbroj bodova pokazuje ekološku i estetsku vrijednost pojedine vrste. * Biljka u sredozemnom području.

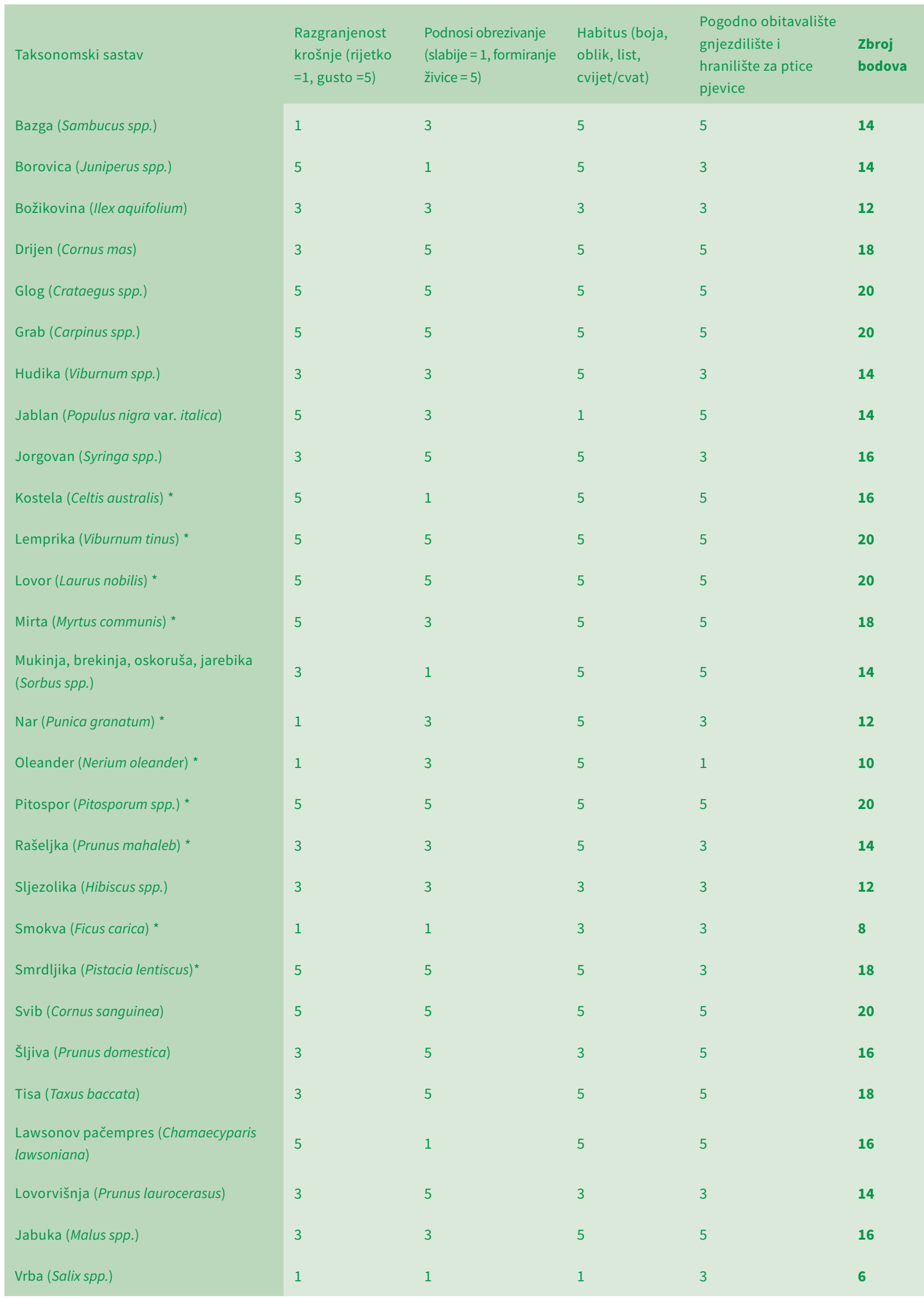




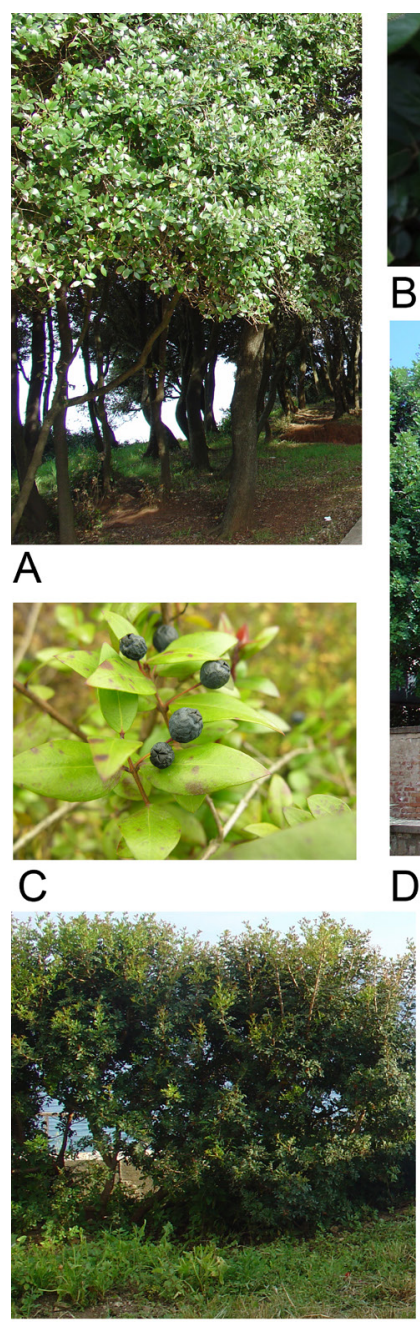

$\mathrm{E}$

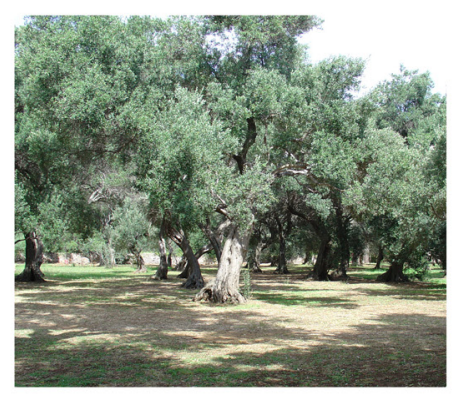

G

Slika 6. Neke pogodne vrste za sadnju u hortikulturi i u privatnim vrtovima (v. Tab. 2) u primorskom dijelu Hrvatske. Lovor (A), lemprika (B), mirta (C), rogač (D), smrdljika (E), rašeljka $(F)$, maslina $(G)$, oleander (H). Fotografija C - Vanja Stamenković.
Za zelenu infrastrukturu u Zagrebu važni su parkovi u kojima gradske službe održavaju biološku raznolikost. Utvrđena je značajna korelacija između pokrivenosti vegetacijom $i$ indeksa diverziteta ptica (Clergeau i sur. 1998). Ptice su osjetljive na promjene sastava i strukture staništa te su mjera biološke raznolikosti (Gregory i sur. 2003, Sandström i sur. 2006) i pogodni su indikatori promjena u urbanom prostoru (Savard i sur. 2000). U parkovima grada Zagreba dobro je saditi domaće bjelogorično grmlje, što pokazuju ornitološke analize. Najmanju brojnost ptica imaju gradske površine sa zelenim površinama na kojima nedostaje grmlja (Kralj i sur. 2013). Grmlje privlači ptice oblikom krošnje i brojem kukaca koji grmlje naseljavaju (Southwood 1961), te plodovima kojima se hrane. Rekreativni park Bundek u Zagrebu siromašan je grmljem čime ne doprinosi biološkoj raznolikosti (Sl. 4). Na velikim livadama, bar uz njihove rubove, treba dopustiti prirodno širenje grmlja i živice s grmovitim i dekorativnim vrstama koje u nas uspijevaju u prirodnim staništima i izgrađuju prirodne šikare i šibljake, kao što su glog, svib, drijen. Grmlje je na različit način razgranjeno i ne podnosi jednako obrezivanje, nosi plodove koji su hrana pojedinim vrstama ptica ili je stanište za insekte kojima se hrane određene vrste ptica. Prema takvim kriterijima odabrao sam 27 rodova/vrsta grmlja i drveća koje bi u našim krajevima mogle biti ekološki vrijedne za sadnju u parkovima i privatnim vrtovima (Tab. 2). U kontinentalnom dijelu Hrvatske to su npr. drijen, glog, grab, jablan, jorgovan, svib, šljiva, tisa, lawsonov pačempres, jabuka, a u primorju npr. lemprika, lovor, mirta, pitospor, smrdljika (Sl. 5 , 6). Vrste dekorativnog grmlja koje je privlačno pticama jer nosi za njih jestive plodove su npr. bazga, drijen, glog, mirta, mukinja, brekinja, oskoruša, jarebika, tisa ili neke voćke. Zanimljivo je da drveće koje se često sadi po parkovima; hrast, vrba, breza, jablan ili jabuka naseljavaju brojni insekti, dok npr. grab ili božikovinu naseljava manje kukaca, pa je na takvom drveću nejednak broj insektivornih ptica (Southwood 1961). Grab je pogodan za obrezivanje, a zimi često ne odbacuje suho lišće do proljeća, pa 

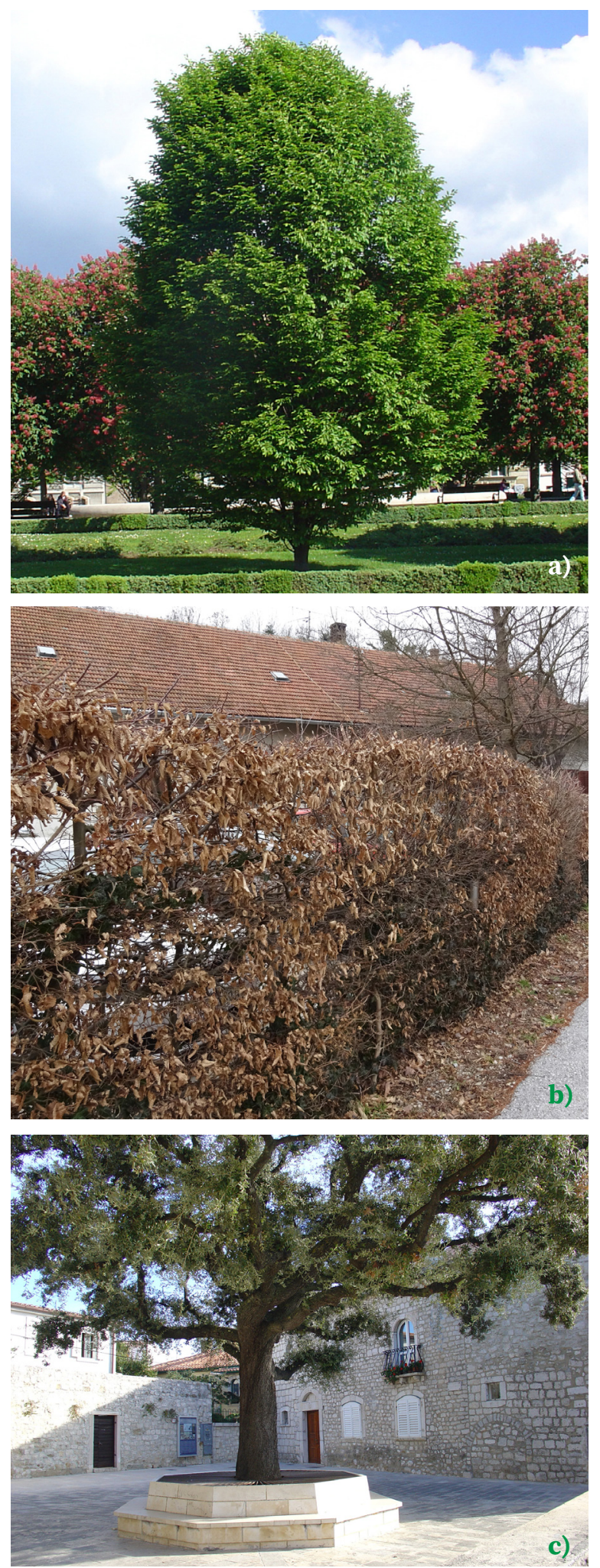

Slika 7. Drveće naših šuma koje je dekorativno i dobro uspijeva u hortikulturi; grab $(\mathrm{A}, \mathrm{B}) \mathrm{u}$ kontinentalnom i hrast crnika $(\mathrm{C}) \mathrm{u}$ primorskom dijelu Hrvatske. čini dobar zaklon za ptice i vizualnu prepreku ako je potrebna. Hrast crniku treba u primorskom dijelu Hrvatske nastaviti saditi kao nekada jer je naša i dekorativna vrsta na javnim površinama (Sl. 7).

Nepravilno upravljanje sa zelenilom pogotovo može biti štetno u primorskom dijelu Hrvatske gdje su gradovi najvećim dijelom građeni od kamena (Sl. 8).

Edukacija u školama o koristima biološke raznolikosti u gradovima neophodna je za senzibiliziranje djece o zaštiti okoliša. Najbolje se to postiže aktivnim sudjelovanjem djece u uređivanju školskih vrtova (S1. 9), gdje mogu shvatiti važnost različitih staništa i zajednica u životu čovjeka, ulogu različitog bjelogoričnog grmlja, livada košanica, nekošenih livada i drugih.

U Zagrebu predstoje veliki projekti (Zagreb na Savi, Medvednica u središtu grada) koje treba riješiti poštujući ekološke zakonitosti kako bi građani grada Zagreba u budućnosti živjeli u zdravom okolišu. Projekt Sava u središtu Zagreba velik je izazov u budućnosti. Postojeće prirodne vrijednosti uz obale rijeke Save u Zagrebu trebalo bi očuvati i uključiti u ekološki optimalna urbanistička rješenja (Sl. 10). Javne površine uz korito rijeke bilo bi dobro organizirati tako da su pokrivene različitim staništima (i životnim zajednicama) u najpovoljnijem rasporedu, koja mogu biti ugodna za boravak ljudi

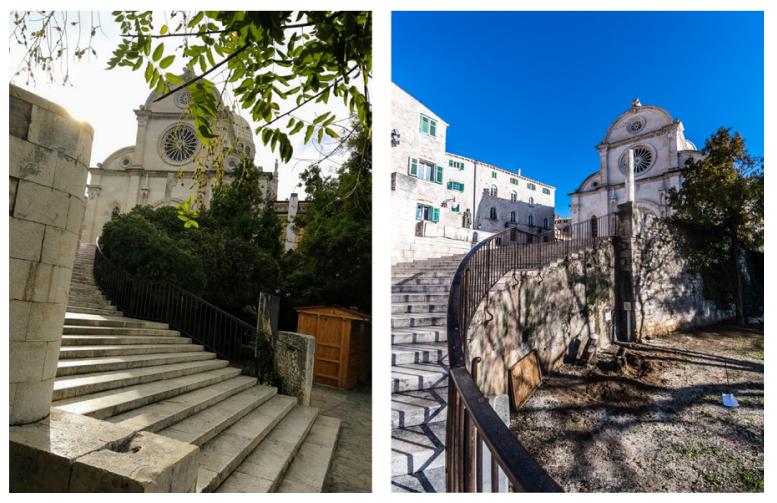

Slika 8. Sjeća pitospora u Šibeniku osiromašila je grad zelenilom i vizuru katedrale (Fotografije: Danijela Smolek Lengelic i Valerio Baranovic, Portal ŠibenikIN). 


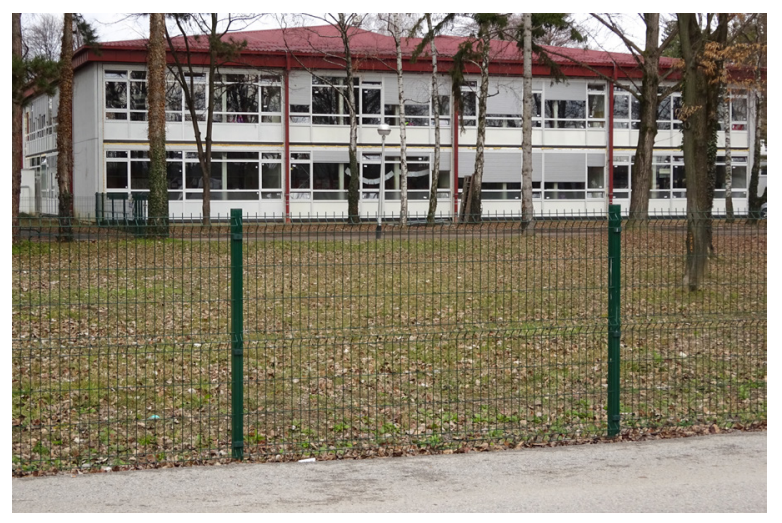

Slika 9. Biološku raznolikost trebaju njegovati škole, sadnjom grmlja uz ograde svojih dvorišta.

na otvorenom, za rekreaciju i edukaciju. To je težak zadatak u uvjetima financijskih pritisaka (Farrell 2017).

Trebale bi nas inspirirati ideje koje se razvijaju u razvijenim gradovima (kao što su London, Copenhagen, Oslo, Malmö), gdje se unatoč financijskim pritiscima pridaje značajna pažnja društvenoj ulozi javnog prostora (Carmona i sur. 2019). Danas se tamo ulaganja uz brojne inovacije usmjeravaju $\mathrm{u}$ javni prostor u skladu s javnim politikama za održavanje prostora za prikladan i zdrav život čovjeka, socijalnu integraciju različitih populacija i ekonomsku konkurentnost gradova. Građani se uključuju u stvaranje novih javnih prostora uz

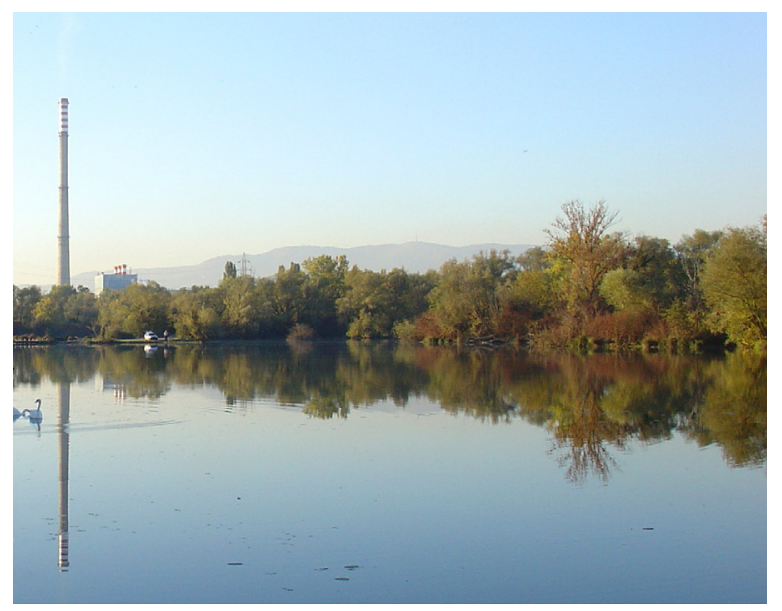

Slika 10. Meandri uz Savu vrijedne su zalihe flore i faune nizinskog dijela grada Zagreba. sufinanciranje koje osigurava nacionalna vlada i lokalne zajednice (općine) te privatne zaklade.

Zaključno, suvremeno urbano planiranje bavi se krajobraznim oblikovanjem ali i krajobraznom ekologijom. Naši gradovi će se povečavati i treba ih uređivati uz ekološke principe, kako bi zelena tehnologija omogućila ugodan i zdrav život građana. Za takve zahvate potrebne su moderne ideje zelene tehnolologije.

\section{Literatura}

Adler, F.R., Tanner, C.J. (2013): Urban ecosystems. Ecological principles for the built environment. Cambridge University Press, Cambridge.

Barrett, G. (2003): Eugene P. Odum: Pioneer of ecosystem science. Bulletin of the Ecological Society of America 84: 11-12.

Bolund, P., Hunhammar, S. (1999): Ecosystem services in urban areas. Ecological Economics 29: 293-301.

Carić, H. (2016): Perspektive razvoja zelenog turizma koncept, politike, primjena. Okrugli stol Prirodna baština i turizam, HAZU, Zagreb: 29-46.

Carmona, M., Hanssen, G.S., Lamm, B., Nylund, K., Saglie, I.-L. Tietjen, A. (2019): Public space in an age of austerity. Urban Design International 24: 241-259.

Clergeau, P., Savard, J-P.L., Mennechez, G. and Falardeau, G. (1998): Bird abundance and diversity along an urban-rural gradient: a comparative study between two cities on different continents. Condor 100: 413-425.

Farrell, T. (2017): There is only one thing worse for urban design than a recession, and that is a boom. Journal of Urban Design 22: 137-139.

Forman, R.T.T. (2014): Urban ecology. Science of cities. Cambridge University Press.

Gaston, K.J., Warren, P.H., Thompson, K., Smith, R.M. (2005): Urban domestic gardens: the extent of the resource and its associated features. Biodiversity and Conservation 14: 3327-3349 
Giddings, B., Hopwood, B., O’Brien, G. (2002): Environment, economy and society: fitting them together into sustainable development. Sustainable Development 10: 187-196.

Gregory, R.D., Noble, D., Field, R., Marchant, J., Raven, M., Gibbons, D.W. (2003): Using birds as indicators of biodiversity. Ornis Hungarica 12-13: 11-24.

Hartig, T. (2008): Green space, psychological restoration, and health inequality. The Lancet 372: 1614-1615.

Johnson, S., Dominiguez-Garcia, V., Donetti, L., Munoz, A. (2014): Trophic coherence determines food-web stability. Proceedings of the National Academy of sciences of the United States of America 111: 17923-17928.

Kralj, J., Tutiš, V., Ćiković, D., Barišić, S. (2013): Ptice kao indikatori kvalitete zelenih gradskih površina. Zbornik radova s međunarodnoga znanstvenog skupa „Zelenilo grada Zagreba“, HAZU, Zagreb: 294 - 303.

McMichael, A. J., Bolin, B., Costanza, R., Daily, G. C., Folke, C., Lindahl-Kiessling, K. i sur. (1999): Globalization and the sustainability of human health. BioScience 49: 205-210.

Odum, E. P. (1969): The strategy of ecosystem development. An understanding of ecological succession provides a basis for resolving man's conflict with nature. Science 164: 262 - 270.

Pedersen Zari, M. (2018): The importance of urban biodiversity - an ecosystem services approach . Biodiversity International Journal 2: 357-360.

Pereković, P., Aničić, B., Hrdalo, I., Rechner, I., Andlar, G. (2007): Percepcija osnovnih karakteristika otvorenih prostora u stambenim naseljima - primjer grada Zagreba i Velike Gorice. Društvena istraživanja 16: 1103-1124.
Pereković, P., Kamenečki, M. (2017): Parkovni elementi kao nositelji rekreacijskog potencijala. Prostor 25: 342-357.

Price, E.L., Sertić Perić, M., Gustavo Q., Romero, G.Q., Kratina, P. (2019): Land use alters trophic redundancy and resource flow through stream food webs. Journal of Animal Ecology 88: 677-689.

Sandström, U.G., Angelstam, P., Mikusinski, G., (2006): Ecological diversity of birds in relation to the structure of urban green space. Landscape and Urban Planning 77: 39-53.

Savard, J-P. L., Clergeau, P., Mennechez, G. (2000): Biodiversity concepts and urban ecosystems. Landscape and Urban Planning 48: 131-142.

Southwood, T.R.E. (1961): The number of species of insect associated with various trees. Journal of Animal Ecology 30: 1-8.

Šišić, B. (2003): Vrtni prostori povijesnog predgrađa Dubrovnika : od Pila do Boninova. HAZU, Dubrovnik.

Taylor, L., Hochuli, D.F. (2015): Creating better cities: how biodiversity and ecosystem functioning enhance urban residents' wellbeing. Urban Ecosystems 18: 747-762.

Taylor Lovell, S, Taylor, J.R. (2013): Supplying urban ecosystem services through multifunctional green infrastructure in the United States. Landscape Ecology 28: 1447-1463.

Urban diversity forum HUB. http://ubhub.org/map (pristupljeno 2.2.2019).

van Heezik, Y., Freeman, C., Porter, S., Dickinson, K. (2014): Native and exotic woody vegetation communities in domestic gardens in relation to social and environmental factors. Ecology and Society 19: 1-14.

Wortman, S.E., Taylor Lovell S. (2013): Environmental challenges threatening the growth of urban agriculture in the United States. Journal of Environmental Quality 42: 1283-1294. 